\title{
PBL (Problem Based Learning) Model Based on Constructivist Sosioculturalism: Theory and Concept of The Millennial Era of Learning Model
}

\author{
Ilfiana Firzaq Arifin', Akhmad Arid Musaddad2, Sudiyanto ${ }^{3}$ \\ 1Universitas Sebelas Maret, Surakarta, Indonesia \\ 2 Universitas Sebelas Maret, Surakarta, Indonesia \\ 3 Universitas Sebelas Maret, Surakarta, Indonesia \\ 1ilfianafirzaq@gmail.com, 2arif_mussadad@yahoo.co.id, 33soeddie.fkipuns@gmail.com
}

\begin{tabular}{ccc}
\hline Received & Accepted & Published \\
$10 / 10 / 2018$ & $09 / 11 / 2018$ & $31 / 12 / 2018$ \\
\hline
\end{tabular}

Abstract Indonesia as a developing country that aspires to improve the quality of education by delivery of human beings who have intelligence that is balanced with high emotional intelligence. Innovation of the learning model is the first step to move forward in advancing the quality of education in this country. The purpose of writing this article is to provide an overview of PBL based learning model constructivist sosioculturalism as an innovative learning model in the millennial era. The method used in this article is descriptive and theoretical analysis with data collected through the study of a variety of articles, books, journals and sources that support the learning model PBL (Problem Based Learning) and constructivist theory sosioculturalism.

Keywords: Learning model, PBL, constructivist sosioculturalism

\begin{abstract}
Abstrak Indonesia sebagai negara berkembang bercita-cita untuk meningkatkan kualitas pendidikan dengan melahirkan manusia yang memiliki kecerdasan yang seimbang dengan kecerdasan emosi yang tinggi. Inovasi model pembelajaran adalah langkah pertama untuk bergerak maju dalam memajukan kualitas pendidikan di negara ini. Tujuan penulisan artikel ini adalah untuk memberikan gambaran tentang model pembelajaran berbasis sosiokulturalisme konstruktivis PBL sebagai model pembelajaran inovatif di era millenial. Metode yang digunakan dalam artikel ini adalah analisis deskriptif dan teoritis dengan data yang dikumpulkan melalui studi berbagai artikel, buku, jurnal dan sumber yang mendukung model pembelajaran PBL (Problem Based Learning) dan teori konstruktivis sosiokulturalisme.
\end{abstract}

Kata kunci : model pembelajaran, PBL, konstruktivis sosiokulturalisme 


\section{INTRODUCTION}

Indonesia once dubbed as the Asian tigers in the world of politics and the economy growing at the time. However, this nickname does not apply in the world of education in our country. Education which is owned by the Indonesian state is not said to be good, but enough, just quality is still far from the level that can be regarded as a country that has the quality of high quality education. Though enrollment in Indonesia is growing significantly, but there are problems that never let up in it that is output from the participation of schools / education still cannot have a strong competitive edge and pretty. This argument is strengthened on the output quality of the HR (Human Resources) which is born of the educational process of our country, its quality is still not encouraging. Launch information Detikfinance.com (2017) Indonesian Finance Minister Sri Mulyani has said that the quality of Indonesian human resources is still inferior to other ASEAN countries, it is proved if we do the tests in the areas of knowledge, skills, and so on along with human resources that include Vietnam, Malaysia, Thailand and other ASEAN countries, the Indonesian human resources will occupy the lowest position in the result as a percentage. The above argument is strengthened by a statement from the World Bank quoted by the daily Kompas.com (2018) states if the quality of human resources in Indonesia is still below other countries in the same region.

If we look back, in 1997 the post crisis shows how education efforts in Indonesia as if it does not work as expected. The role of education in this period as if it did not have power. Violence has been entrenched and even put himself in the culture of our nation as a nation suave. It can be concluded that this is an indication of the result of the work of education of our country. Most persons agreed that indication, but partly not. But if we explore more deeply indeed all that ever happened was the work of the education of our country. So that the failure of education in this country to give birth to a cultured man, especially in his attitude affects the fall of the image of our country in terms of education.

In the millennial era that have become a byword for most people, an era full of changes in various fields one of which is education. This period can be regarded as the modern age, but the level of modernity bears are at a higher level than before. Indonesia is a country that is growing and developing in this era. Bears status as a developing country in the millennial era, pushing the country to become a developed country in many aspects, especially in terms of education like other developed countries in Southeast Asia. Based on bitter experience ever perceived by our country, asking to find and develop new joints in the field of education. So now Indonesia is in transition in the world of education.

In general, the transition made by the Indonesian state, especially in the world of education when it enters the 21st century especially based on three major challenges namely, 1) The world of education is required to maintain the results of educational development that has 
been achieved, 2) The world of education is required to prepare human resources competent in the field so that it can compete in the era of globalization, 3) the national education system in demand to perform adjustment and change so as to realize a democratic educational process with regard to diversity, the need / local circumstances and learners and encourage community participation.

The idea of transformation in the field of education conducted by the Indonesian state is now nothing more than to build a society that has a good characteristic in the eyes of the world as well intellectualism, because Indonesia is a country east known as a country rich nobility, good manners, which is based on culture framing our country. Of course, to realize the noble ideals is not easy, it takes a wide variety of efforts in education should be done as a driving force for our country to reach his goal. This is a tough task but precious for the realization of a dream that is knitted with conviction and sincerity.

One of the efforts made to meet the demand for changes in various joints in the body of education, changes to components of the learning model is an initial phase to renovate education in our country. Based on various phenomena that have occurred in our country renovations to the learning model focused on the learning model that is based on a constructivist approach, in this case the constructivist used is constructivist sosioculturalism that aims to teach students that the human life can never be separated from the culture inherent since its inception in themselves. So that all acts and their horns are based on a culture that is closest to its environment. PBL learning model is a model of problem-based learning are selected to be combined with a constructivist approach sosioculturalism. This learning model will be used as a model of innovative learning, which not only relies on problem-based learning, but also on this model can construct the attitude of the students toward a better direction as expected by our country in the era of the millennial nowadays so with presence PBL models like this will be to boost the quality of education of our country.

The purpose of writing this article is to give an overview of the theories and concepts of the model PBL (Problem Based Learning) based on constructivist learning model innovative sosioculturalism as required in the millennial era like the present. Such a model is a model of learning that is needed in the face of the global millennium era that change so quickly. So that in the state of Indonesia requires an innovative learning model to prepare Your new human beings in the face of the changing dynamics of social life globally.

\section{METHOD}

The method used in this article is to use descriptive and theoretical analysis of the PBL and constructivist sosioculturalism with data obtained from a wide variety of books, journals and other sources of support. 


\section{RESULT AND DISCUSSION}

\section{Problem Based Learning}

If we discuss about PBL, arising therein discuss a wide range of perspectives on this topic. There is of some people who say that PBL is an approach to learning, and have also said that PBL is a model of learning that is used to convey the subject matter. Departing from a different perspective about the PBL and therefore will be reviewed on the PBL which according to some figures and PBL is an approach that according to some figures is also a learning model.

PBL can be regarded as a learning approach that includes interdisciplinary learning (Stentoft, 2017), So with this approach he thinks will create a more conducive learning atmosphere. But unlike that expressed by Keegan (2017) which revealed that PBL is a constructivist andragogic complementary approach which means that this approach is an approach that emphasizes active learning by means of guiding students to develop an understanding of their own based on the knowledge they gained from the experience they get from the outside and their living environment. Furthermore, Keegan also explain that PBL can also be regarded as andragogic approach means that such an approach is an approach to learning that emphasizes the importance of problem-based learning with completing engineering problems based on real evidence.

The learning model PBL (Problem Based Learning) is a learning model that encourage students to engage actively in the learning activities to construct their knowledge based on problems given by educators / teachers. According to Ivicek (2011) in his journal writes that PBL is a learning model that uses collaborative techniques to easily solve the problem scenario that has been given by the educator. According to PBL also an instructional model that involve students actively work through case studies rather than just receive information passively delivered through lectures teachers. More deeply, Ivicek also confirmed that PBL is an instructional model that generates critical thinking skills to students. Critical thinking techniques is meant by Ivicek is analyzing the skills of the existing literature they can get from a teacher or experiences they have been through.

Opinions of Ivicek above, reinforced with the opinion of the Swart (2018) who said that PBL is an instructional model that emphasizes the identification of problems (problem solving) to resolve the problem by way of critical thinking and using collaborative learning techniques to create a conducive learning atmosphere. In theory advanced by this Swart, then he also uses the concept of learning by involving the three core aspects of learning that is visual, auditory and kinesthetic. Visual aim to recall what they had seen before, auditory aims to recall what they had heard, and kinesthetic aims to recall what they had done the days before. From the use of these three aspects in the teaching and learning of the theory of Swart, the PBL aims to learn to 
create a conducive learning atmosphere. So, the students not only learn to run a learning model that already exists, but here students are also taught to create a learning environment that is in line with expectations Swart, so the role of the students here not only as a major player but also as a creator of atmosphere.

PBL is an instructional model that is rarely used in learning. Yet the presence of such PBL learning model can help students to be more active in the process of learning, so that what is required by our country towards young people (students) can be achieved with the implementation of this PBL models. As disclosed by Young Kim (2014) PBL has said that the model has been successfully used by many disciplines in the world of education in the period over these last 30 years. Because as has been described above previously, the model PBL is very nice to be applied to the students because in addition to learning model is centered on the students, they are also trained to learn and apply knowledge and skills to solve problems such as in the real world but in context based on relevant and authentic evidence.

The main factor PBL is still rarely used in schools that this model is still undefeated with conventional learning models such as lectures. Most teachers believe that every model of learning that renewable unenforceable if it is not combined with lectures. Though learning lecture is focused only on the teacher, so the teacher alone is visible only active in learning activities, not to students. It's okay to renewable models such as PBL combined with a model of learning such as lectures in the classroom with the intention to convey a bit of explanation as an introduction to applying the learning model that is renewable as PBL. Savery (2006), borrowing term from Barrows (2002) which defines the primary key in the PBL that there are four elements which is considered important in implementing PBL models namely:

First, structural problems that are not good / bad is the main way for students to be active in learning to look for alternatives to solve these problems by smoking. Buffer category these problems come from the environment the students themselves who sometimes occur every day in her life (Ge, 2004), Second, students should be able to respond well in their own learning. From here they must decide what they have to learn and where they get the information to resolve such issues of books, journals or other literature that support. Thirdly, the teacher acts as a facilitator only, nothing more than that. The facilitator here serves to provide what students should learn in PBL models and as an escort if students have difficulties in learning. Fourth, authenticity in carrying out each step in the PBL. The point is awarded to the student issues are issues relevant to the students.

If we review a little about what is contained in the curriculum in Indonesia that encourages learning should involve students actively involved in learning, but in practice it is not so. Indeed, in the middle of the lesson plans created by teachers themselves, written in it that says that the teaching and learning activities teachers are already using innovative 
instructional model as one that is operating the PBL students to be actively involved in the learning process while the teacher only as a designer or facilitator. However, actual field conditions do not justify what he had written in black ink on that paper. As described above, the teacher still struggling with the conventional learning models such as lectures.

So it can be concluded that, PBL is a model or an approach to learning that serves to activate students in the learning activities to hone the ability to think critically and explore their skills in thinking so that output of the model PBL will make boys and girls Indonesia has a quality that can compete with the outside world because of the learning process that happens in school is learning that not only centered on the teacher as was done in earlier times, but his condition has turned to student-centered learning.

\section{Constructivist Theory Sosioculturalism}

Since 1990, the constructivist approach is very important to be applied in designing the study. Why use a constructivist approach to learning is because there are three assumptions about learning and learning using the constructivist approach: First, learning is the process of making meaning of knowledge simplified. This implies that students should be able to build their knowledge in the learning that comes from what they have experienced for their developments simply to become a knowledge that is both simple as well. Second, create social relationships with fellow human beings become more meaningful. This means students must be actively interact with their peers to develop their knowledge, and students should be able to feel the atmosphere of comfortable interaction as a result of the interaction of their own so that they can create and modify their knowledge with their peers. Third, the learning has its own place in relation to nature. This means that students should be able considered sociocultural circumstances and sociohistorical in creating a learning rule.

Opinions of Jonassen above, in contrast to the opinion of the Guzzini (2005) although equally mentioned three characteristics by using constructivist learning. Guzzini mention that the characteristics of constructivist learning which includes three basic characteristics: First, constructivist can build and control the social sciences. Second, constructivist can build a network of relationships in the social world. Third, constructivist can differentiate between knowledge-based social constructivist and constructivist based social reality.

In this constructivist approach, Hendry (1996) reveal different things with Guzzini and Jonassen as described above. Associated with the characteristics constructivist, Hendry suggests three main key in implementing a constructivist approach to learning that is: First, knowledge comes from the mind of every person. Second, all of the information they obtain logically processed by their own knowledge. Third, knowledge is built on the interrelation with the world system. Fourth, the knowledge is uncertain. Fifth, the general knowledge is run by the brain and the effect on the body that have become part of the universal. Sixth, knowledge is built 
through a process of apperception and action. Seventh, in building knowledge requires a lot of manpower and time.

Paradigm use a constructivist approach to learning is based as the basic capital in learning to be easier to educate students (Hendry, 1996), The capital aimed at shaping the knowledge and character of students in tune with the historical and cultural students. In addition, the use of a constructivist approach to learning is to see the final outcome of the learning process itself that produces a product development knowledge (Garneau, 2014), Constructivist approach is considered very important to be applied in the country of Indonesia. Given this state is a state that has a cultural and historical basis are very thick at all and therefore it is proper if Indonesia must improve the quality of education using the constructivist approach based sosioculturalism as one donor in education for the sake of advancement of the quality of education in the State Indonesia. The approach to learning using the constructivist approach sosioculturalism, because the condition of the field at this time the actual student should be able to wrestle with the environmental conditions in the culture is considered closest to them. By struggling and recognize the inherent cultural environment with students,

Sosioculturalism constructivist approach is believed to be an approach that develops knowledge and comes from a cultural environment which is considered closest to the students. Vygotsky (1960) said that by using constructivist sosioculturalism then they will form their own characters preceded by their immediate living environment. Vygotsky also emphasized the importance of community and the (environment culturally). So, it is evident here that Vygotsky emphasized the importance of socio-cultural environment and directly Vygotsky provide that the constructivist approach, combined with socio-cultural. It described by Vygotsky above, similar to that described by Lyddon (1992) which explains that knowledge is built using the constructivist approach sosioculturalism originated and evolved instead of the human mind itself, but rather from the interaction with the surrounding environment so that this knowledge can form and thrive in the human mind.

Sociocultural constructivist theory was well received by teachers in schools. Because this theory provides a way to be able to consider the psychological and social. Why culturally environment? Because culturally environment is a place where someone every day to interact in it in order to establish the knowledge and character they are. So what someone is doing the most to absorb from the environment around them to stay. For example, one can do good, because he sees the surrounding cultural environment did these good deeds. Likewise, with an if done badly, it is because he absorbed what he saw from surrounding cultural environment in which he lives. This is in accordance with the opinion of the Borovoi (2016) who said that knowledge cannot stand alone, there must be a contributor and the main character in it as the social and cultural life. Furthermore, Sahal (2018) said that in the context of cultural education 
cannot be separated from the culture of the environment as a system of social interactions. So, cultural environment is very influential and accounted for nearly $75 \%$ of its knowledge and character is built by someone.

From the reasons as above, then in a country like Indonesia is considered very precisely to implement the constructivist approach sosioculturalism because of the condition of our country historically and socially is a country rich in culture, so the character inherent in an individual that different regions will have different anyway, The implication of what they apply in everyday life will be different, adjust to what they absorb from since he was born.

\section{Concept Model-Based PBL Constructivist Sosioculturalism}

It is appropriate, when a country wants to make himself as developed countries, there should be an effort to achieve the mission. Progress who want to be perceived by every country not just in one area only, but a wide range of fields, even almost the entire field attempted to move forward for a country a country that is respected and respected by other countries. As the Indonesian state is currently very eager to advance the quality of education towards the better. Because as described above, the Indonesian state educational quality if viewed from the perspective of the world is still relatively far away from the words of the advanced and qualified. It is true, many students and student / student from Indonesia who excel out there. Even, not infrequently Indonesian students and gold medals won in a variety of Olympicorganized by the International side.

However, it was only a handful, even if we draw a comparison figure into \pm 1 : 100 students who excel bring good name of the nation. However, the state of education in Indonesia beloved country is encouraging every stakeholder in education to renovate every organ that becomes an obstacle to the development of education in the country of Indonesia. PBL is a kind of model of learning that has been frequently applied in Indonesia. However, although the models are already being applied in the country of Indonesia, the expected output is still far from their targets. Perhaps, some wrong of the concepts and syntax learning or are there other things that PBL can be said that the results are still not good. For that PBL should conceptualized and packaged in such a way in order to function properly and the result is maximum.

PBL model with actual students can use critical thinking techniques rather than simply relying only memories (AJ Swart, 2010) because the concept in PBL is complete and solve a problem with the technique of working groups both small groups or large groups. In line with the opinion of the above Swart, Tayyeb (2013) also expressed his opinion that the PBL is an effective learning models to be applied because it can improve students' critical thinking. But usually, PBL like this just dwell on problems based on a problem that is not real. Thus, students only know the condition of which they never happen in real life. 
PBL concept like this can not continue, because students live in a social environment that every day see a wide variety of reality. PBL like it ought to be modified with a constructivist approach sosioculturalism of Lev Vygotsky, in which he said that human will never escape from culturally environment. Constructivist-based concept sosioculturalism PBL is to create students understand the social environment where he was born, grow and thrive. So that students can recognize and know the state of the environment and a wide range of reactions there. Sosioculturalism constructivist-based PBL is very important to apply to the students of Indonesia, because Indonesia is a country rich in culture. While culture should always be preserved because it is inherited from ancestors. So from there, little by little knowledge will be formed by the environment in which students live.

PBL-based constructivist sosioculturalism, but can build knowledge that is built from experience obtained by students from the surrounding environment, can also shape the character of the students towards the better. Because as we known today, a lot of Indonesian students academically even though he is a very clever student, but if we look from the emotional side is very far from the academic side. So that the balance between the two is almost nonexistent. That is because, wrong view of education. Education is not just created to create a clever man in terms of academic course, but there must be a balance between academic and emotional. But it applies and there is in the country of Indonesia. The views of each community that education is for it to become academically smart man, so that the human race to pursue an education only to create academic brilliance in him, not with emotional intelligence. So, do not be surprised if the quality of education in Indonesia is less advanced countries.

The task of the constructivist-based concept of PBL is to fix these. So, the concept of constructivist-based PBL sosioculturalism like what is needed? PBL model concept is based sosioculturalism constructivist educators implement PBL models as usual he applied daily to the students, but here its PBL sosioculturalism combined with a constructivist approach. The unification between constructivist models sociocultural, PBL with this by giving educators a problem to the students, but the problem is based on the real conditions taken from a nearby neighborhood with students. So, from here, the students will easily construct and solving problems given by educators, because it is definitely their assumption that problem had almost happened to him every day. Then, after students completely look for alternative answers given by the teacher, then the student can automatically absorb about what he was talking about. From there, students also can automatically learn a lesson that still has not he knew from the neighborhood where they live. This constructivist-based PBL, besides teaching students to think critically, can also introduce students to social life that lives in their midst. So that students can recognize the surrounding environment well. 


\section{CONCLUSION}

Model PBL is a learning model that is applying the concept of problem-based learning and create opportunities for students to think critically somehow. But the problem is usually given to the students is a problem that comes from the textbook only, not the real problem comes from the neighborhood students. With constructivist sosioculturalism approach, PBL models into a model that can boost the quality of education in Indonesia. Because this model is not only asking the students to think critically alone, it invites students to get to know the environment is culturally where he lived to sensitize them which they will never be separated from the environment culturally because they are born into a world filled with culture so that what they are doing and behavior or their character comes from the environment disenfranchised. Thus, the purpose of the concept of PBL learning-based constructivist sosioculturalism are create Indonesian become learners multiple intelligence, which is smart academically and emotionally intelligent, so this will boost the quality of state education Indonesia in the eyes of the world, because the output of education in Indonesia is not only intelligent academically but also emotionally.

\section{REFERENCES}

Barrows, H.. (2002). Is It Truly Possible To Have Such a Thing as the PBL? Distance Education, $23,119-122$.

Borovoi, L. (2016). Social Informatics in Education: Societal Cultures Versus Educational Technologies. Journal of Bulletin of Science, Technology and Society, 35 (5-6), 178-186.

Detikfinance.com. (2017). Sri Mulyani Talk RI HR Quality Compared to other ASEAN countries. Retrieved from https://finance.detik.com/beritaekonomi-bisnis/d3780811/srimulyani-bicara-kualitas-sdm-ridibanding-negara-asean-lain

Garneau, AB (2014). Cultural Competence: A Constructivist Definition. Journal of Transcultural Nursing, 26 (1), 9-15.

Ge, X. (2004). A Conceptual Framework For Scaffolding Ill-Structured Problem Solving Processes Using Prompts Question and Peer Interactions. Educational Technology Research and Developments, 52 (2), 5-22.

Guzzini, S. (2005). The Concept of Power: A Constructivist Analysis. Journal of International Studies, 33 (3), 495-521.

Hendry, GD (1996). Constructivism and Educational Practice. Australian Journal of Education, $40(1), 1945$.

Ivicek, K. (2011). Using Problem Based Learning for Occupational and Environmental Health Nursing Education: Pesticide Exposures Among Migrant Agricultural Workers. AAOHN, $59(3)$. 
Jonassen, D.. (2000). Theoretical Foundation of Learning Environments. New York: Lawrence Erlbaum.

Keegan, LC (2017). Problem Based Learning and Civic Engagement in Undergraduate Education. Quarterly Journal of Communication Disorders, 39 (1), 312-319.

Kompas.com. (2018). Call the World

Bank Competitiveness Still Low HR Indonesia. Retrieved from https://ekonomi.kompas.com/read/ 2018/06/06/202118826/worldbank-sebut-dayasaing-sdmindonesia-masih-rendah

Lyddon, W. . (1992). Constructivist Psychology: A Heuristic Frame Work. Journal of Mind and Behavior, 13(1), 89-108.

Sahal, M. (2018). Tolerance in Multicultural Education: A Theoritical Concept. International Journal of Multicultural and Multireligious Understanding, 5(4), 115-122.

Savery, J. . (2006). Problem Based Learning: Definitions and Distinctions. The Interdiciplinary Jounal of Problem Based Learning, 1(1), 9-20.

Stentoft, D. (2017). From Saying to Doing Interdisciplinary Learning: Is Problem Based Learning The Answer? Active Leraning in Higher Education, 18(1), 51-61.

Swart, A. . (2010). Evaluation of Final Examination Papers in Engineering: a Case Study Using Bloom's Taxonomy. IEEE Trans Educ, 53, 257-264.

Swart, AJ (2018). With African Enganging Stundents Engineering Problem Based Learning by Using The dissasembly-Assembly Technique. International Journal of Electrical Engineering Education, 0 (0), 1-14.

Tayyeb, R. (2013). Effectiveness of Problem Based Learning as an Instructional Tool for Acquisition of Content Knowledge and Promotion of Critical Thinking Among Medical Student. Journal of the College of Physicians and Surgenons Pakistan, 23, 42-46.

Vygotsky, L. (1960). Razvitie Vysshikh Psikhicheshkikh Funktsii (The Development of the Higher Mental Function). Moscow: Akad.Ped.Nauk.RSFSR.

Young Kim, D. (2014). AdoptingProblem Based Learning in Criminology and Criminal Justice Education: Challenge and Response. Criminal Justice Department, 1-13. 